\title{
INSCRIÇÕES POÉTICAS: MATERNIDADES
}

\section{[sem título]}

\author{
Ela ensaia uma cambalhota \\ e como quem desfaz um nó \\ me convida a rir \\ de seu movimento desajeitado
}

\author{
Nos olhamos \\ e agora buscam \\ cada um \\ a sua toada \\ Ela respira \\ E retraça a rota \\ para nova tentativa \\ $* * *$ \\ VIVA! \\ [grito meu serpenteia o céu da sala] \\ Abrigadas no tempo dos começos \\ Por um instante \\ Fazemos pouco da morte \\ que, \\ dona das ruas, \\ nos espia pela janela.
}

com a cumplicidade festiva de corações que já animaram um mesmo corpo

\section{Fabiana Carneiro da Silva}

Neta de Amada e de Quitéria, filha de Lourdes, mãe de Imani. Tece um caminho que alinhava docência, pesquisa e ações artísticas no campo dos saberes contra-hegemônicos, sobretudo a partir do eixo constituído por literatura, corpo e experiência comunitária. Doutora e mestre em Teoria Literária e Literatura Comparada pela Universidade de São Paulo (USP), atua como professora adjunta no Departamento de Letras Clássicas e Vernáculas do Centro de Ciências Humanas, Letras e Artes da Universidade Federal da Paraíba (UFPB). Concebeu e codirige a série Literatura inteira e o projeto artístico Mulher meio-fio. Coordena o projeto Tessituras Negras: ateliê de leituras literárias e práticas pedagógicas. Foi professora na rede básica de ensino e em projetos sociais, âmbito no qual destaca a proposição de oficinas de escrita autobiográfica para/com mulheres quilombolas. É membro permanente do Programa de Pós-Graduação em Ensino e Relações Étnico-Raciais (PPGERUFSB), integra o Grupo de Pesquisa Sobre o corpo feminino - literaturas africanas e afro-brasileira (UNILAB-CE) e o grupo de pesquisa ALDEIA: Núcleo de pesquisas afro-brasileiras em Artes, Tradições e Ensinagens na Diáspora (UFSB). Autora do livro Ominíbú: maternidade negra em Um Defeito de Cor (EDUFBA, 2019). Desenvolve estudo sobre a produção artística negro-brasileira, sobretudo literária, dedicando-se à análise dessas poéticas e à formulação de práticas de ensino a partir delas. E-mail: fabicarneirodasilva@yahoo.com.br 


\section{Umbigo}

Como quem faz carinho

Em sua bisavó

Minha filha toca

Esse coração aberto

No centro do meu corpo-terra

Umbigo

Em idioma antigo

me grafa enredos

Que apenas a palma

da mãozinha dela

sabe ler

me lavra sonhos

Que quiçá a palma

da mãozinha dela

poderá colher

\section{Eu Cariri}

Aquela minha bisavó

De quem não vi retrato

De quem não ouvi relato

E muito menos documentação

Abriu no tempo

Uma picada

E me entregou um mapa

Todo ali o Cariri

Caninana, a minha dança

Semente-juá, meu olhar

Pequizeiro-em-flor, o coração

E língua essa é romaria-multidão

Dia após dia,

contra a queda do céu

aquela minha bisavó

me encontra

mas não me diz quem eu sou

Ela me olha

e na certeza de que eu sei quem ela é

me investe de esperança

sentida

feito chuva em mata seca

Recebido em 21/03/2021.

Aceito em 20/o6/2021. 